\title{
CONSUMER BASKET IN UKRAINE: A REGIONAL ASPECT
}

\author{
Oksana TKHOREVSKA, 'Anastasiia USHCHAPOVSKA \\ Taras Shevchenko National University of Kyiv, Ukraine \\ 'itsmenastya@mail.ru
}

\begin{abstract}
The article uncovers the consumer basket significance in formation and realization of social policy in Ukraine. The price of the consumer basket determines the living wage and ultimately, all other social standards, guarantee payments and assistance. Nowadays, there is a considerable mismatch between consumer basket composition and basic foods consumption rates of ukrainians: content of consumer basket doesn't meet even minimal human needs. The amount of basic foods, except bakery products, in the consumer basket is much less than the rational and even the minimum rates required for a healthy diet, and actual consumption in Ukraine. In general, the weight structure of the consumer basket is outdated because it does not correspond to the present structure of food consumption. The authors have analyzed the ratios of regional consumer basket cost to key indicators of population welfare and identified 4 groups of administrative units acoording to the consumer basket cost to the key financial indicators of population well-being ratio.
\end{abstract}

Key words: consumer basket, social standards, consumption rates, regional differences, living wage, population welfare.

UDC: 911.3

\section{СПОЖИВЧИЙ КОШИК В УКРАЇНІ: РЕГІОНАЛЬНИЙ АСПЕКТ}

\author{
ОКсана ТХОРЕВСЬКА, 'Анастасія УЩАПОВСЬКА \\ Київський начіональний університет імені Тараса Шевченка, Україна \\ 'itsmenastya@mail.ru
}

\begin{abstract}
Анотація: Розкрито значення споживчого кошика у формуванні і проведенні соціальної політики в Україні. Вартість споживчого кошика визначає величину прожиткового мінімуму і, в кінцевому рахунку, всі інші соціальні стандарти, гарантовані виплати та допомоги. У наші дні існує значна невідповідність між обсягом споживчого кошика та структурою і обсягом споживання основних продуктів харчування в Україні: вміст споживчого кошика не відповідає навіть мінімальним потребам людини. Обсяг основних продуктів харчування, за винятком хлібобулочних виробів, у споживчому кошику значно менший раціональних і навіть мінімальних норм, визнаних необхідними для здорового харчування, а також фактичного споживання в Україні. Загалом, структура споживчого кошика застаріла, оскільки вона не відповідає сучасній структурі споживання продуктів харчування. Автори проаналізували регіональні співвідношення вартості споживчого кошика та основних показників добробуту населення і виявили 4 групи адміністративно-територіальних одиниць згідно з співвідношенням вартості споживчого кошика та основних фінансових показників добробуту населення.
\end{abstract}

Ключові слова: споживчий кошик, соціальні стандарти, норми споживання, регіональні відмінності, прожитковий мінімум, добробут населення

УДК: 911.3

Statement of the problem

The living wage indicator is used as the nominal rate for social guarantees calculating in Ukraine. The basis for calculating the living wage for both social and demographic groups is the cost of a minimum set of food, services and nonfood items that are commonly called consumer basket $(\mathrm{CB})$. The price of the consumer basket determines the living wage and ultimately, all other social standards, guarantee payments and assistance [7]. In this context, analysis of Ukrainian consumer basket composition, its compliance with basic foods consumption rates, regional interrelations of consumer basket cost and key indicators of population welfare requires particular attention.

Analysis of recent researches and publications

The problematics of the Ukraine's population polarization by income is disclosed in the works of the Institute of Demography and Social Policy experts. Human geographical essence of socio-spatial polarization of the

(C) О. Тхоревська, А. Ущаповська population is revealed in the writings of I. V. Hukalova, K. V. Mezentsev, G. P. Pidhrushnyi, N. I. Mezentseva, L. M. Nyemets, M. O. Baranovskiy [1; 3; 5]. Actually legislative aspects of the formation and functioning of Ukrainian consumer basket, methods of calculation of this indicator are considered in the works of V. A. Baluk, K. O. Kovyazina, A. F. Melnyk and other scientists.

\section{Target setting}

The purpose of this paper is a comparative analysis of the consumer basket content and consumption rates of basic foods by Ukrainians and identifying regional differences of the consumer basket cost to the key indicators of population welfare ratio.

\section{Main study material}

With the entry into force of the Law of Ukraine "On Living Wage" (1999) the term "consumer basket" implies sets of food, services and non-food items, necessary for an individual to meet his/her basic social and cultural needs applied to calculation of a living wage [7].

The content of the Ukrainian consumer basket is governed by the Order of Cabinet of Ministers of 
Basic food consumption rates in Ukraine

(per person per year, $\mathrm{kg}$ )

\begin{tabular}{|l|c|c|c|c|}
\hline Basic foods & $\begin{array}{c}\text { Minimum } \\
\text { rates }\end{array}$ & $\begin{array}{c}\text { Rationale rates } \\
\text { (MHU calculations) }\end{array}$ & $\begin{array}{c}\text { Actual consumption } \\
\text { in 2012 }\end{array}$ & $\begin{array}{c}\text { Consumer basket } \\
\text { rates }\end{array}$ \\
\hline $\begin{array}{l}\text { Bread and bakery } \\
\text { products }\end{array}$ & 94 & 101 & 109,4 & 123,4 \\
\hline Meat and meat products & 52 & 80 & 54,4 & 53 \\
\hline Milk and dairy products & 341 & 380 & 214,9 & 148,5 \\
\hline Fish and fish products & 12 & 20 & 13,6 & 13 \\
\hline Eggs (pcs.) & 231 & 290 & 307 & 220 \\
\hline Vegetables and melons & 105 & 161 & 163,4 & 110 \\
\hline Fruits, berries and grapes & 68 & 90 & 53,3 & 64 \\
\hline Potato & 96 & 124 & 140,2 & 95 \\
\hline Sugar & 32 & 38 & 37,6 & 37 \\
\hline Vegetable oil of all kinds & 8 & 13 & 13 & 7,1 \\
\hline
\end{tabular}

* Compiled by the authors based on $[4 ; 6]$

Ukraine \# 656 of 14.04.2000. It should be noted, that in accordance to Ukrainian legislation it should be reviewed every 5 years. Indeed, consumer basket in Ukraine hasn't been reviewed since its ratification [4]. Nowadays content of consumer basket doesn't meet even minimal human needs. There is a mismatch between the minimum, rational medical consumption rates of basic foods, recommended by Ukrainian Research Institute of food Hygiene of the Ministry of Healthcare (MHU), and consumer basket rates (Table 1).

This indicators ratio shows that consumer basket rates don't only meet the rational consumption rates of basic foods, but also are lower than minimum ones.

In particular, the worst ratio is typical for such products as milk and milk products (56\% less than the minimum rates), oil (less than 11\%), fruits, berries and grapes (less than 6\%), eggs (less than $5 \%$ ). Even potato consumption is $1 \%$ less than the minimum rates. The rest of the consumer basket rates are higher than the minimum food consumption rates. In particular, bread and bread products by $31 \%$, sugar by $16 \%$. However, consumption of these two types of products shows just about a low level of purchasing power and irrational structure of nutrition.

Consumer basket rates don't meet the main foods rational consumer rates at all, except bread and bakery products which are $22 \%$ higher than the rational rates. The worst consumer basket to rational rates ratio is characteristic of milk and dairy products that equals $39.1 \%$.

As for the ratio between consumer basket rates and the actual food consumption the positive percentage is typical only for two foods: fruits, berries and grapes $(120 \%)$ and bread and bakery products $(120 \%)$. The worst ratio is characteristic for oil $(-45.5 \%)$, potatoes, vegetables and melons $(-32 \%)$ and milk and dairy products $(-30.9 \%)$. The rest of consumer basket rates are significantly lower than the actual basic foods consumption in Ukraine.

In 2012, the consumer basket cost (the living wage) in Ukraine was 1042.42 UAH. As key financial indicators of human well-being we used the rates of average salary (ES), minimum income (the average pension in the regions), cash income and cost of population (Table 2).

Comparison of these data allowed us to identify regional aspect of Ukrainian consumer basket cost to key indicators of population welfare ratio.

The table above demonstrates that the average share of consumer basket cost as a part of the average salary of Ukrainians was little more than a third (34.38\%). Regional differentiation of average salary can objectively be explained by the location of profitable companies (their central offices and most highly paid jobs are located in the capital and the Kyiv oblast), highly industrialized eastern part of country and substantial state support (subsidies) of these productions, regional urbanization level (in cities earnings are higher). In addition, the sectoral structure of regional economy may affect in some way: service workers had the highest salaries during last years.

As an indicator of population minimum income, we used the average pension in the regions. The best consumer basket cost to minimum income of population ratio is observed in the Kyiv city, the worst - in Ternopil oblast (it is the only region, where the average pension is less than a living wage). This situation can be explained by the largest government budget expenses in the form of subsidies to the pension fund (Kyiv city and Donetsk oblast), spread of illegal labour emigrants (especially in the western areas - Ternopil oblast) who don't pay labour taxes, and also by standard of wages, because they determine the amount of that contributions and thus is the basis for the future pension payments. High average pensions in the capital and in the Donbas are also explained by the fact of many retirees living here, whose pensions are governed by special laws.

In general, the cost of the consumer basket in Ukraine makes up $74.83 \%$ of its population cash income. The smallest share of the consumer basket cost compared to the cash income of population - less than a half, is officially recorded in the city of Kyiv (47.5\%), the 
Table 2

Ukrainian consumer basket cost as part of the key indicators of population welfare: regional analysis, 2012

\begin{tabular}{|c|c|c|c|c|c|c|c|c|}
\hline \multirow[b]{2}{*}{ Regions } & \multicolumn{2}{|c|}{ Average salary } & \multicolumn{2}{|c|}{$\begin{array}{l}\text { Minimum income of } \\
\text { population }\end{array}$} & \multicolumn{2}{|c|}{$\begin{array}{l}\text { Cash income of } \\
\text { population }\end{array}$} & \multicolumn{2}{|c|}{ Cash of population } \\
\hline & $\begin{array}{c}\text { per } \\
\text { person, } \\
\text { UAH }\end{array}$ & $\begin{array}{c}\% \text { of } \mathrm{CB} \\
\text { cost }\end{array}$ & $\begin{array}{c}\text { per } \\
\text { person, } \\
\text { UAH }\end{array}$ & $\begin{array}{c}\% \text { of } \mathrm{CB} \\
\text { cost }\end{array}$ & $\begin{array}{c}\text { per } \\
\text { person, } \\
\text { UAH }\end{array}$ & $\begin{array}{c}\% \text { of } \mathrm{CB} \\
\text { cost }\end{array}$ & $\begin{array}{c}\text { per } \\
\text { person, } \\
\text { UAH }\end{array}$ & $\begin{array}{c}\% \text { of } \mathrm{CB} \\
\text { cost }\end{array}$ \\
\hline $\begin{array}{l}\text { Autonomous Republic } \\
\text { of Crimea }\end{array}$ & 2784.67 & 37.43 & 1169.83 & 89.11 & 1474.11 & 70.72 & 1348.66 & 77.29 \\
\hline Vinnytsia & 2445.08 & 42.63 & 1066.2 & 97.77 & 1297.89 & 80.32 & 1262.67 & 82.56 \\
\hline Volyn & 2346.83 & 44.42 & 1076.54 & 96.83 & 1175.75 & 88.66 & 969.03 & 107.57 \\
\hline Dnipropetrovs'k & 3141.08 & 33.19 & 1314.91 & 79.28 & 1504.58 & 69.28 & 1261.55 & 82.63 \\
\hline Donets'k & 3511.25 & 29.69 & 1481.66 & 70.35 & 1818.22 & 57.33 & 1415.70 & 73.63 \\
\hline Zhytomyr & 2372.42 & 43.94 & 1088.87 & 95.73 & 1241.88 & 83.94 & 1148.61 & 90.76 \\
\hline Zakarpattya & 2363.25 & 44.11 & 1044.98 & 99.76 & 1200.59 & 86.83 & 1091.67 & 95.49 \\
\hline Zaporizhia & 2932.25 & 35.55 & 1258.86 & 82.81 & 1503.29 & 69.34 & 1455.55 & 71.62 \\
\hline Ivano-Frankivs'k & 2544.00 & 40.98 & 1095.4 & 95.16 & 1155.93 & 90.18 & 1062.95 & 98.07 \\
\hline Kyiv & 3168.83 & 32.90 & 1237.38 & 84.24 & 1499.99 & 69.50 & 1193.43 & 87.35 \\
\hline Kirovohrad & 2431.67 & 42.87 & 1101.82 & 94.61 & 1410.78 & 73.89 & 1167.80 & 89.26 \\
\hline Luhans'k & 3105.08 & 33.57 & 1433.41 & 72.72 & 1610.32 & 64.73 & 1400.63 & 74.43 \\
\hline Lviv & 2580.08 & 40.40 & 1121.32 & 92.96 & 1299.41 & 80.22 & 1114.03 & 93.57 \\
\hline Mykolaiv & 2833.17 & 36.79 & 1141.37 & 91.33 & 1487.10 & 70.10 & 1462.44 & 71.28 \\
\hline Odessa & 2709.83 & 38.47 & 1152.06 & 90.48 & 1573.36 & 66.25 & 1203.89 & 86.59 \\
\hline Poltava & 2854.67 & 36.52 & 1166.07 & 89.40 & 1381.10 & 75.48 & 1160.38 & 89.83 \\
\hline Rivne & 2582.83 & 40.36 & 1085.15 & 96.06 & 1125.14 & 92.65 & 930.50 & 112.03 \\
\hline Sumy & 2504.67 & 41.62 & 1114.15 & 93.56 & 1224.66 & 85.12 & 1012.18 & 102.99 \\
\hline Ternopil & 2191.25 & 47.57 & 1017.12 & 102.49 & 1056.49 & 98.67 & 997.83 & 104.47 \\
\hline Kharkiv & 2759.25 & 37.78 & 1188.62 & 87.70 & 1454.09 & 71.69 & 1281.32 & 81.35 \\
\hline Kherson & 2274.5 & 45.83 & 1084.68 & 96.10 & 1281.60 & 81.34 & 1195.21 & 87.22 \\
\hline Khmelnytskyi & 2428.92 & 42.92 & 1066.1 & 97.78 & 1219.94 & 85.45 & 1052.26 & 99.06 \\
\hline Cherkasy & 2511.67 & 41.50 & 1110.13 & 93.90 & 1357.94 & 76.76 & 1407.25 & 74.08 \\
\hline Chernivtsi & 2332.08 & 44.70 & 1046.49 & 99.61 & 1295.43 & 80.47 & 1185.41 & 87.94 \\
\hline Chernihiv & 2311.25 & 45.10 & 1105.06 & 94.33 & 1374.56 & 75.84 & 1324.20 & 78.72 \\
\hline Kyiv & 4610.58 & 22.61 & 1640.54 & 63.54 & 2197.20 & 47.44 & 1943.90 & 53.63 \\
\hline Ukraine & 3031.92 & 34.38 & 1223.25 & 85.22 & 1393.13 & 74.83 & 1232.66 & 84.57 \\
\hline
\end{tabular}

* Compiled by the authors based on [6]

largest (almost 99\%) - in Ternopil oblast. The difference between the best and the worst ratio is more than 2 times, it means that the average Kyivan on his/her income could buy two consumer baskets of goods and services, while the residents of Ternopil oblast could barely be able to afford such a basket. The level of registered income is influenced, in addition to the defined factors, by the unemployment rate and the labour force participation rate as the ratio between the labour force and the overall regional population.
Most households cash costs per capita in regions of Ukraine dominate by over the living wage or consumes basket cost, on average within a country - by $15 \%$. The Kyivans spend the most money, whose expenses are more than consumer basket cost by almost twice as much. According to official statistics, the least household cash cost are in Rivne oblast, where the population spends less than the consumer basket cost - as much as $12 \%$. Also cash costs are less in relation to the living wage in Volyn, Ternopil, and Sumy oblasts. Besides the above 
Ranking of the regions of Ukraine on the consumer basket cost to the key financial indicators of population well-being ratio (2012)

\begin{tabular}{|c|c|c|c|c|c|c|c|c|c|}
\hline Regions & 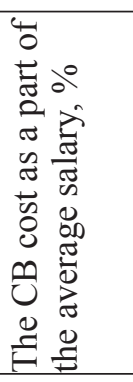 & Rank & 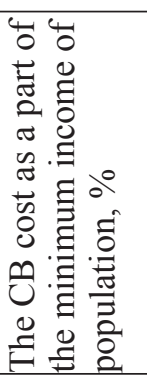 & Rank & 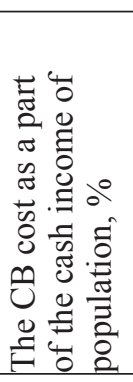 & Rank & 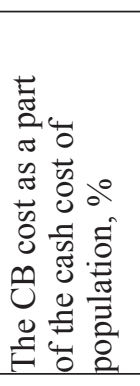 & Rank & $\Sigma$ Ranks \\
\hline $\begin{array}{l}\text { Autonomous } \\
\text { Republic of Crimea }\end{array}$ & 37.43 & 9 & 89.11 & 8 & 70.72 & 9 & 77.29 & 7 & 33 \\
\hline Vinnytsia & 42.63 & 17 & 97.77 & 22 & 80.32 & 16 & 82.56 & 10 & 65 \\
\hline Volyn & 44.42 & 22 & 96.83 & 21 & 88.66 & 23 & 107.57 & 25 & 91 \\
\hline Dnipropetrovs'k & 33.19 & 4 & 79.28 & 4 & 69.28 & 5 & 82.63 & 11 & 24 \\
\hline Donets'k & 29.69 & 2 & 70.35 & 2 & 57.33 & 2 & 73.63 & 4 & 10 \\
\hline Zhytomyr & 43.94 & 20 & 95.73 & 18 & 83.94 & 19 & 90.76 & 18 & 75 \\
\hline Zakarpattya & 44.11 & 21 & 99.76 & 25 & 86.83 & 22 & 95.49 & 20 & 88 \\
\hline Zaporizhia & 35.55 & 6 & 82.81 & 5 & 69.34 & 6 & 71.62 & 3 & 20 \\
\hline Ivano-Frankivs'k & 40.98 & 14 & 95.16 & 17 & 90.18 & 24 & 98.07 & 21 & 76 \\
\hline Kyiv & 32.90 & 3 & 84.24 & 6 & 69.50 & 7 & 87.35 & 14 & 30 \\
\hline Kirovohrad & 42.87 & 18 & 94.61 & 16 & 73.89 & 11 & 89.26 & 16 & 61 \\
\hline Luhans'k & 33.57 & 5 & 72.72 & 3 & 64.73 & 3 & 74.43 & 6 & 17 \\
\hline Lviv & 40.40 & 13 & 92.96 & 12 & 80.22 & 15 & 93.57 & 19 & 59 \\
\hline Mykolaiv & 36.79 & 8 & 91.33 & 11 & 70.10 & 8 & 71.28 & 2 & 29 \\
\hline Odessa & 38.47 & 11 & 90.48 & 10 & 66.25 & 4 & 86.59 & 12 & 37 \\
\hline Poltava & 36.52 & 7 & 89.40 & 9 & 75.48 & 12 & 89.83 & 17 & 45 \\
\hline Rivne & 40.36 & 12 & 96.06 & 19 & 92.65 & 25 & 112.03 & 26 & 82 \\
\hline Sumy & 41.62 & 16 & 93.56 & 13 & 85.12 & 20 & 102.99 & 23 & 72 \\
\hline Ternopil & 47.57 & 26 & 102.49 & 26 & 98.67 & 26 & 104.47 & 24 & 102 \\
\hline Kharkiv & 37.78 & 10 & 87.70 & 7 & 71.69 & 10 & 81.35 & 9 & 36 \\
\hline Kherson & 45.83 & 25 & 96.10 & 20 & 81.34 & 18 & 87.22 & 13 & 76 \\
\hline Khmelnytskyi & 42.92 & 19 & 97.78 & 23 & 85.45 & 21 & 99.06 & 22 & 85 \\
\hline Cherkasy & 41.50 & 15 & 93.90 & 14 & 76.76 & 14 & 74.08 & 5 & 48 \\
\hline Chernivtsi & 44.70 & 23 & 99.61 & 24 & 80.47 & 17 & 87.94 & 15 & 79 \\
\hline Chernihiv & 45.10 & 24 & 94.33 & 15 & 75.84 & 13 & 78.72 & 8 & 60 \\
\hline Kyiv & 22.61 & 1 & 63.54 & 1 & 47.44 & 1 & 53.63 & 1 & 4 \\
\hline Ukraine & 34.38 & & 85.22 & & 74.83 & & 84.57 & & \\
\hline
\end{tabular}

* Compiled by the authors based on [6]

factors, labour migration can influence (in the form of financial transfers, or remittances between immigrants and family members who are still residents of Ukraine, or by improving the welfare of that migrants).

Having summarized the above-mentioned ratio and ranked regions of Ukraine on consumer basket cost as a part of key financial indicators of population well- being, we have identified 4 groups of administrative units (Table 3):

1). region with the best ratio between the consumer basket cost and population welfare indicators - Kyiv city and oblast;

2). regions with satisfactory ratio between the consumer basket cost and population welfare indicators - 
predominantly eastern and southern regions of Ukraine;

3). regions with unsatisfactory ratio between the consumer basket cost and population welfare indicators - most of the central and western regions;

4). regions with the worst ratio between the consumer basket cost and population welfare indicators - mainly western and north-western regions, the worst situation of which can be clearly seen in the Ternopil oblast (Figure 1).

\section{Conclusions and further research}

Ukrainian consumer basket approved 14.04.2000 and never revised, now is the basis for all social guarantees calculation. As a result, the composition of the consumer basket does not meet modern human needs. The amount of basic foods, except bakery products, in the consumer basket is much less than the rational and even the minimum rates required for a healthy diet and actual consumption in Ukraine. In general, the weight structure of the consumer basket is outdated because it does not correspond to the present structure of food consumption (consumption of vegetables and melons, meat and milk have increased during the last 15 years and consumption of flour products, potatoes have reduced). Taking into account new models of nutrition becoming more relevant all over the world to promote healthy lifestyles, healthy eating, vegetarianism, we can expect a significant change in population's nutrition structure.

The consumer basket cost, which is called the living wage, is not able to provide a decent life for the Ukrainians. After analyzing the ratio between the consumer basket cost and key indicators of population welfare, we found significant regional differences and identified on that basis 4 groups of administrative units, including the optimal situation evolved only in Kyiv. In our view, the development of new calculating methods of the consumer basket of Ukraine should take into account regional differentiation of not only the cost of living and population needs, but internal potential of regions and peculiarities of their development.
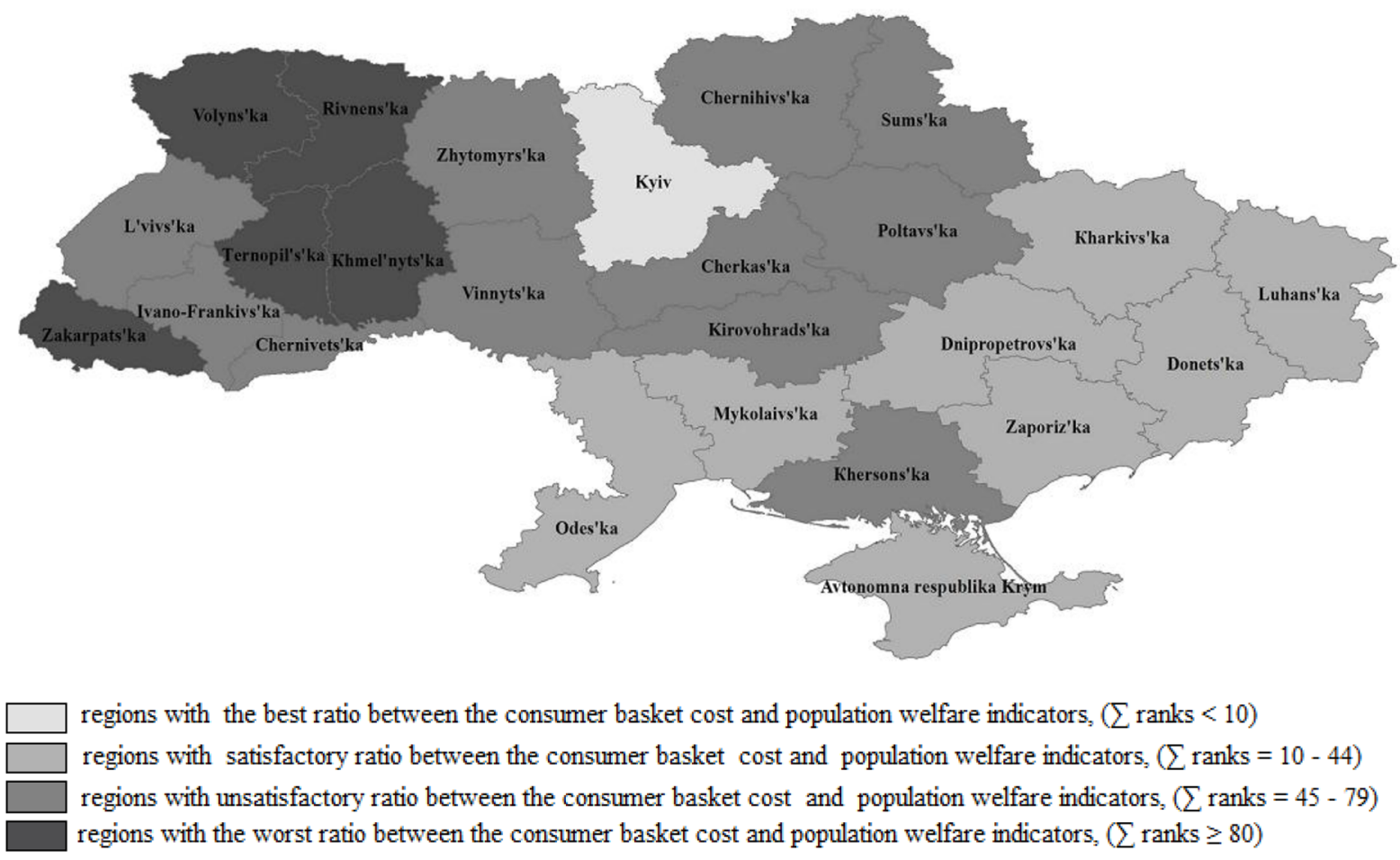

regions with the best ratio between the consumer basket cost and population welfare indicators, $\left(\sum\right.$ ranks $\left.<10\right)$

regions with satisfactory ratio between the consumer basket cost and population welfare indicators, $\left(\sum\right.$ ranks $\left.=10-44\right)$

regions with unsatisfactory ratio between the consumer basket cost and population welfare indicators, $\left(\sum\right.$ ranks $\left.=45-79\right)$

regions with the worst ratio between the consumer basket cost and population welfare indicators, $\left(\sum\right.$ ranks $\left.\geq 80\right)$

\begin{abstract}
Fig. 1. Ranking of the regions of Ukraine on the consumer basket cost to the key financial indicators of population well-being ratio (2012)

* Compiled by the authors based on [F]
\end{abstract}

\title{
References:
}

1. Gukalova İ. V. Âkist' žittâ naselennâ Ukraïni: suspil'no-geografična konceptualizaciâ: monografîa [Quality of life in Ukraine: human geographical conceptualization: Monograph]. Kyiv, 2009, 346 p. (In Ukrainian).

2. Kovâzìna K. O. Ŝodo udoskonalennâ metodiki viznačennâ spoživčogo košiku. Analitična zapiska [As for improving the methodology for determining the consumer basket: Policy Brief]. Access mode: http://www.niss.gov. ua/articles/1233/ (In Ukrainian).

3. Mezencev K. V., Pìdgrušnij G. P., Mezenceva N. İ. ' rozvitok v Ukraïnì: suspil'no-prostorova nerìvnist' i polârizaciâa: Monografiâ [Regional development in Ukraine: socio-spatial inequality and polarization: Monograph]. Kyiv, 2014, 132 p. (In Ukrainian).

4. Nakaz Kabìnetu Mìnistrìv Ukraïni «Pro zatverdžennâ naborìv prodovol'čih, neprodovol'čih tovarìv ta poslug dlâ osnovnih social'nih ì demografičnih grup naselennâ» \# 656 vid 14 kvitnâ 2000 roku [The Order of Cabinet of 
Ministers of Ukraine «On approval of the sets of food, nonfood items and services for the major social and demographic groups" \# 656 dated 14 April 2000]. Access mode: http://www.niss.gov.ua/articles/1233/ (In Ukrainian).

5. Nemec' L. M. Ustojčivoe razvitie: social'no-geografičeskie aspekty (na primere Ukrainy): Monografiâ [Sustainable development: socio-geographic aspects (evidence from Ukraine): Monograph] / Kharkiv, 2003, 383 p. (In Russian).

6. The official website of the State Statistics Service of Ukraine. Access mode: http://ukrstat.org/

7. Zakon Ukraïni «Pro prožitkovij minimum» [The Law of Ukraine "On Living Wage"]. Access mode: http:// zakon4.rada.gov.ua/laws. (In Ukrainian). 